\title{
Ecolinguistics in the Cultural Acculturation of the Northern Coastal Communities of Central Java
}

\author{
Riris Tiani*
}

Faculty of Humanities, Diponegoro University, Semarang- Indonesia

\begin{abstract}
The main subject of this research is the ecological lexicon in the northern coastal communities of Central Java. The existence of ecological lexicon in the Northern coastal communities may serve as a form of language attitude of the speech community. The language attitude is not only observable by verbal messages, but Javanese people are closely integrated with the biological environment. The symbols of nature appear to be integrated with the life of the Northern coastal communities of Central Java. These symbols of nature represent the philosophy of life of the Northern Coastal communities of Java who still firmly uphold their faith and belief. The method used was a survey involving questionnaires from several informants at the observation points. Observation points in three major areas of Northern Coast of Central Java were including Demak, Pati, and Rembang. The data were collected by ecolinguistic design. The results of the research showed that the ecological lexicon of Northern coastal communities of Central Java was observable in the designation of agricultural products, especially in the biological environment. This persistence of attitude was manifested in the belief in the ecological lexicon associated with religious rituals. Ecological lexicon was chosen as a symbol of harmonization of human interaction with nature as a fundamental form of integration with their God. In addition to being observable in the ecological lexicon, the language attitude of the Northern coastal communities of Central Java was also seen in the cultural ecology of the Northern coastal communities of Central Java. Cultural ecology appeared in the humility in giving a recpect. The respect is reflected in sedekah laut, sedekah bumi rituals, and in the number of architectural ridges (gunungan) of residential building.
\end{abstract}

Keywords: ecolinguistics; ritual; coast.

\footnotetext{
*Corresponding author : tiani.riris@gmail.com
} 


\section{Introduction}

Nowadays, some linguists argue that languages in various parts of the world have shifted. Mesthrie explained that one-half of the languages in the world have shifted and disappeared [1]. Language experiences a shift when language community members collectively abandon their traditional language and switch to another language. The language shift was also experienced by the Javanese-language community. This only occurs in the Indonesian language. Up to now, there are still 700 archipelago languages spread in various parts of Indonesia.

Language is a component system that has a fixed pattern and can be educated [2]. The education system is influenced by the cultural environment of people that will form the written and spoken culture in accordance with biological phenomena. Biologically, human is a linguistic organism. Ecology is a study of the relationship of organisms with their environment. The study becomes the basis for exploring and analyzing the basic characteristics of populations of living organisms in interacting and adapting to their environment [3].

The life process of a linguistic organism involves the interaction of other organisms, objects, and artifacts in the environment to maintain the ecological system itself. It can be preserved through information understanding, the view of cognition as the distribution of space and time to form and to create the ecological power of their organisms.

After the ecology of linguistic organisms is formed, then in a metaphorically larger environment they will involve social, economic, political aspects, etc. Cowley (2014) explained that linguistic ecology is a way of view to observe the interaction of linguistic organisms (humans) in an nature-based environment [4]. It can be concluded that the linguistic ecology is a study of interactions between language and environment [3]. The language itself is manifested as a human or linguistic organism. Language connects users to one another in understanding nature or social environment. The three foundations in ecolinguistics are: biomorphic metaphors that language is a symbol of organisms that interact with people as the owners of nature; it is said that language is the code or means used to communicate; cognitive internalism means language as a concept that only exists in the minds of its users; and cognitive externalism means that thoughts or ideas must be conveyed to others using language tools.

Linguistic attitude consists of linguistic attitude and non-linguistic attitude. The linguistic attitude is a form of belief systems or cognitions that are collectively and relatively developed from generation to generation. The linguistic attitude can be interpreted as loyalty, pride, and awareness of language. This attitude forms the community to maintain their language. By maintaining their language, they have a proud attitude towards their mother tongue. That pride is the factor to always use mother tongue from generation to generation under any circumstances. Therefore, under the unity of 
linguistic ecology, the communities naturally form a unity and give their identity as a community that has a mother tongue.

Demak, Pati, and Rembang are categorized as one of the Northern coasts in Central Java. With a strategic area, the language used by the community is highly dynamic. Language change is influenced by environmental interactions along with the influence of other languages that enter quickly. Coast is a transitional area and interaction between terrestrial and marine ecosystems. These regions are very rich in natural resources and environmental services called coastal resources. Coastal resources consist of biological and non-biological resources, where biological elements consist of fish, mangroves, coral reefs, seagrass beds and other marine biota as well as their ecosystems, while non-biological elements consist of mineral and other abiotic resources in the coastal areas, in the surface water, in the water column, and on the seabed.

The researcher focused on the interaction of language user's attitudes towards the ecological lexicon in their living environment, especially on the northern coast of Central Java. The Northern coastal communities of Java dominantly use Javanese manners (krama) in their linguistic environment.

A huge influence of cultural acculturation made the Northern Coastal people of Central Java slightly abandon the Javanese manners (krama). One way to preserve it is through the research of liguistic ecology related to attitudes towards the use of Javanese in choosing and establishing ecological lexicon in their living environment.

\section{Method}

The data collection method used in this research is survey method by obtaining data from a certain natural sites. Furthermore, the researcher collected data by distributing questionnaires in three research areas (Demak, Pati, Rembang). Data collection using a questionnaire was strengthened by interviews, participant observation techniques and recording techniques. The survey method in this research was carried out by distributing questionnaires containing a number of questions to obtain information or data from respondents. The data collected through a questionnaire was first classified based on the area of observation, then categorized based on variables that have been determined. Then the data was further analyzed and calculated.

\section{Results and Discussion}

This research is an ecolinguistic research. This study focuses on the ecological lexicon used in the Northern Coastal Environment of Central Java. The use of ecological lexicons represents the language attitude of speech communities. Ecolinguistic research is systematic, controlled, empirical, and critical of the target object in the form of an ecological lexicon. This research is a development of the relationship of human interaction as a language user 
with the environment that is manifested in the form of language, religious rituals, artifacts, and traditional foods.

\subsection{Ecological Lexicon in Myths and Rituals of the Northern Coastal communities of Central Java}

Language is a treasure, and so are flora and fauna. It will be an invaluable asset of a country. Language can reveal the meaning of an architecture or written literary heritage which are all equally important and valuable for use in any field [5].

Ecological lexicons are shown in ancak. Ancak is interpreted as an attacking position. Ancak is used in traditional ceremonies in the Northern Coastal communities in welcoming the birth of the Prophet Muhammad. Ecologically, it is made of woven bamboo which is used to place fruits, various side dishes, and various rice. Bamboo has the Latin name bambusea, a type of grass with cavities and internodes on its trunk. Bamboo has a high philosophical value for coastal communities and several other national cultures. Bamboo as one of the aspects of cultural elements and beliefs of the Javanese coastal community. For the northern coastal communities of Java, bamboo represents a philosophy of life known as ngelmu pring [6]. Bamboo serves as a reflection of the characteristics of the Coastal community of Java. The use of bamboo is believed by the community that the resource can be easily obtained in nature. It can grow in all climates and without being planted by humans. So bamboo is a gift from God that must be utilized by humans. Weaving it after being thinly cut representing the symbol of unity, strength which is tightly bound to one another.

The second ecological lexicon is wos. Wos, which means rice, is the main filler for ancak. Rice is believed by coastal communities to have very high philosophical values. A very strong belief is believed that where you plant rice, it will immediately grow grass around it, but not conversely. Rice is interpreted as ukhrawi (afterlife), then if we pursue the afterlife, all forms of worldliness will automatically also be fulfilled.

The third ecological lexicon is klambil. Krambil is a coconut fruit. In the coastal ritual, two coconuts with two heads are used. The coconut is believed to be a manifestation of biological parents and teacher. Biological parents can reduce the grace while teacher can raise our degrees through useful knowledge. So that in religious rituals, coconut is a must-have fruit.

The fourth ecological lexicon is janur. It is derived from Arabic Ja a nur, which means the coming of light. Janur is used as the main decoration in religious events, such as the wedding celebration because it is believed to have philosophical values in lighting pathway or tetenger in order to lead to the right path.

The fifth ecological lexicon is Naa-naas. Ecologically we know pineapple. It is derived from Arabic Naas-naas while called ananas in Latin which refers to a good person in line with the meaning in Arabic which was later adopted in the philosophy of the Javanese coast, that means human. The 
lexicon has a philosophical value in warning humans, what they were created for. Therefore, it is suggested to understand the contents of surah An-Naas. Then, the sixth one is yasluku. Derived from Arabic Salaka and from Latin Salacca, that means passing through or taking the pathway. Etymologically salaka in Javanese is manifested in salak fruit that has philosophical meaning as a transformation of mental and spiritual attitude by purifying the inner and outer to reach a better spiritual life.

Those six ecological lexicons are deeply struck in coastal communities, especially in religious rituals. The history of environmental ecology explains that the Northern coast as the main area of the spread of Islam in the archipelago, therefore the values of religiosity are still maintained to date.

\subsection{Ecologiculture of Communities in the Northern Coast, Central Java}

Ecolinguistic concepts can be arranged in four foundations: symbolic ecology, natural ecology, sociocultural ecology, cognitive ecology [7]. Symbolic ecology in the environment of Northern Coastal communities of Central Java is a symbol of language involved in patterns of interaction in communities realized in religious rituals and realized with sedekah bumi. Sedekah bumi involves biological elements originated in nature. Human interaction with the environment is based on nature [3] through symbols that appear in the ecological lexicon.

Natural ecology is a dynamic mutual interaction between humans and their environment. For the the northern coastal communities of Central Java, sea is an extraordinary asset. It is a source of natural power for life. Given resources such as fish, seaweed, mangroves and coral reefs are natural biological ecosystems. The results of the interaction of natural ecology with human creativity and initiative can produce ponds, rice fields, agro-tourism and agro-industry. As a result, it developed into a maritime country that is rich in ecological lexicon.

Sociocultural ecology of language is the code or means used to communicate. Javanese people has a complex level of expression of respect for others' feelings [8]. The form of respect for the environment can be seen in the ritual of sedekah bumi which are performed following the seasonal change in the North coastal environment, for example sedekah laut and sedekah bumi as the representation of gratitude for the abundant catch of fish and agriculture. Harmonization with the environment is always well maintained and passed down from generation to generation.

Cognitive ecology means language as a concept that only exists in the minds of its users. Concepts, ideas and thoughts are transformed in the form of artifacts (home architecture buildings). The view of life and attitudes of the Northern Coastal communities of Java are full of the philosophy of life as a symbolic manifestation of noble values in the building of house. Thus, the persistence of attitude can be seen in the position of the bathroom and kitchen in the coastal communities of Java that is always separated from the main 
house. It means that the house is a sacred place to return to God. It is inappropriate if the main house is built next to the bathroom and kitchen as a manifestation of worldly desires merged with the main house.

\section{Conclusion}

The ecological lexicon of the northern coastal communities of Central Java is represented in the denomination of agricultural products, especially in the biological environment. The persistence of attitude is manifested in the belief in the ecological lexicon associated with religious rituals. Ecological lexicon is chosen as a symbol of the harmonization of interaction of human with nature as a fundamental form of integration with their God. In addition to be seen in the ecological lexicon, the language attitude of the Northern coastal communities of Central Java is also found in the cultural ecology of the northern coastal communities of Central Java. The cultural ecology appears in the humility in giving a respect. The respect is reflected in the sedekah laut, sedekah bumi rituals, and the number of architectural ridges (gunungan) of the residential building.

\section{References}

1. Mesthire, R. Language Loyalty, Bernard (Ed) Concise Encyclopedia of Educational Linguistics. Amsterdam: Esevier (2009).

2. Chaer \& Agustina. Sosiolinguistik: Perkenalan Awal. Jakarta: Rineka Cipta (2010).

3. A.V. Kravchenko. Two Views on Language Ecology and Ecolinguistics (2015).

http://dx.doi.org/10.1016/j.langsci.2015.12.002

4. Cowley, S.J. Bio-ecologi and Language: a necessary unity.lang.sci.41, 60-70 (2014).

5. Perez, Isabel Corral. Indigenous Languages Identity and Legal Framework in Latin America: An Ecologilinguistics Approach. Procedia Social Behavioral Science 212 (2015) 111-116 (2015).

http://creativecommons.org/licences/by-nc-nd/4.0

6. Anderson, Benedict. Mitologi dan Toleransi Orang Jawa. Yogyakarta: Jejak (2008).

7. Steffensen, Sune Vork. Ecolinguistics: The State of The Art and Future Horizons. Language Sciences. Volume 41 part a. 2014.6-25 (2014). https://doi.org/10.1016/j.langsci.2013.08.003

8. Tiani, Riris. Cultural Environtment in Coastal Islamic Boarding School Regarding The Form of Politeness To Kyai. E3s web of conferences 125 Icenis (2019).

https://doi.org/10.1051/e3sconf/201912509002 